\title{
Cover Memo: Volume 18, Issue 2, Special Issue on Climate Change Solutions
}

\section{Dame Karen Pierce, DCMG}

Her Majesty's Ambassador to the United States of America

https://doi.org/10.38126/ISPG1802CM

This Special Issue of the Journal of Science Policy \& Governance has been sponsored by the United Kingdom Foreign, Commonwealth and Development Office's Science and Innovation Network (UK SIN).

It is my great pleasure to introduce this special issue of the Journal of Science Policy and Governance (JSPG) on Climate Change Solutions, sponsored by the UK government's Science \& Innovation Network. This 18th Volume of the JSPG comes at a critical moment in accelerating global climate ambition to safeguard the future of our planet. If we are to succeed in tackling the challenges of the climate emergency, bold and decisive policy-making, grounded in science, will be more important than ever before.

The last decade was the hottest ever recorded. In 2020, global surface temperatures were between $1.2^{\circ} \mathrm{C}$ and $1.3^{\circ} \mathrm{C}$ warmer than pre-industrial levels - the hottest year on record. The science is clear. We need to act now, together, to reduce emissions and avoid catastrophic consequences for humanity. There are no easy solutions to the challenges before us, but we know we need to go further and innovate faster; leveraging policy levers informed by cutting-edge science and listening to the voices of those most impacted by climate change.

Six years on from the COP21 climate summit, where world leaders pledged to limit the increase in the global average temperature to well below $2^{\circ} \mathrm{C}$ and pursue efforts to limit the increase to $1.5^{\circ} \mathrm{C}$, the UK will host the 26th UN Climate Change Conference of the Parties (COP26) in Glasgow, in partnership with Italy. A successful summit in November will be crucial to achieving the objectives of the Paris Agreement - but governments cannot tackle the climate crisis alone. COP26 will bring together heads of state, climate experts, business leaders and campaigners to agree coordinated action to address climate change.

The UK has already taken important steps towards meeting the Paris Agreement goals. We were the first major economy in the world to pass laws to bring all our greenhouse gas emissions to net zero by 2050; our Nationally Determined Contribution commits the UK to reducing economy-wide greenhouse gas emissions by at least $68 \%$ by 2030 , compared to 1990 levels; and we have doubled our international climate finance to at least $£ 11$.6bn over the next five years. But we know we have more to do.

Ahead of COP26, and as we build back better from COVID-19, the UK will be aiming to raise ambition at home and abroad to follow through on commitments to reduce carbon emissions and create a safer, healthier, more prosperous future. Here in the US, our diplomatic mission integrates climate into everything we do. We are committed to working with US federal and State governments and City Halls, civil society, companies and people on the frontline of climate change to make mid-century net zero targets a reality and pursue a green transition that grows the economy, while ensuring no one is left behind.

In November, it will be critical for governments and non-state actors to come together to:

\section{Secure global net zero by mid-century and keep $1.5^{\circ} \mathrm{C}$ within reach}

To achieve the Paris Agreement goals, countries will need to set science-based 2030 emissions reductions targets that align with reaching net zero by the middle of the century. 


\section{Adapt to protect communities and natural habitats}

We need to work together to protect and restore ecosystems, and build defences, warning systems, and resilient infrastructure and agriculture to save homes, livelihoods and lives.

\section{Mobilise finance}

Developed countries must make good on their promise to mobilise at least $\$ 100 \mathrm{bn}$ in climate finance per year and work with international financial institutions to unleash the trillions in private and public sector finance required to secure global net zero.

\section{Work together to deliver}

We need to accelerate action to tackle the climate crisis through collaboration between governments, businesses and civil society.

The papers in this issue offer much-needed perspectives on the biggest challenges facing our planet. I offer my congratulations to the authors for their contributions to the fight against climate change, and my thanks to the editors and staff of the JSPG for enabling the next generation of STEM leaders to make their voices heard. I also hope that this issue will inspire you to think urgently, collaboratively and innovatively about the task ahead so we can seize this opportunity to build a better future, together.

\section{Dame Karen Pierce DCMG (Mrs Karen Roxburgh)}

Prior to arriving in DC, Dame Karen Pierce was the United Kingdom's Permanent Representative to the United Nations in New York since March 2018. Prior to this role, Dame Karen served as the Director General for Political Affairs and Chief Operating Officer of the Foreign and Commonwealth in London, from 2016.

Dame Karen joined the Foreign \& Commonwealth Office in 1981. Her first role was in Tokyo between 1984 and 1987, after which she returned to the UK to work in the Security Policy Department. Karen worked in Washington as the Private Secretary to the British Ambassador to the United States between 1992 and 1995. Between 1996 and 2006, Dame Karen held several positions in London including Team Leader for Ukraine, Belarus and Moldova, Deputy Head of Eastern Adriatic (Balkans) Department, Head of Newsroom, Head of EU Department (Bilateral) and concurrently Head of Afghanistan Political Military Unit after 9/11 before returning to the Balkans as Balkans Coordinator from 2002 to 2006.

In 2006, Dame Karen moved to New York for the first time to be the Deputy Permanent Representative and Ambassador at the UK Mission to the UN. In 2009, she returned to London to become the Director of South Asia and Afghanistan Department and the UK's Special Representative for Afghanistan and Pakistan. In 2012, Dame Karen started her second multilateral role, this time in Geneva, where she was the Ambassador and Permanent Representative to the UK Mission to the United Nations, World Trade Organization and Other International Organisations until 2015. Between 2015 and 2016 Dame Karen was the UK's Ambassador to Afghanistan. 